\title{
The Development of a Political Awareness Scale and Psychometric Testing on Nurses in Turkey: A Methodological Study ${ }^{1}$
}

\author{
Hilal KUŞCU-KARATEPE ${ }^{2} \&$ Aytolan YILDIRIM $^{3}$
}

\begin{abstract}
This study was carried out to develop a Political Sensitivity Scale for nurses and to demonstrate its validity and reliability. This study was prepared in methodological design. Data were collected between June 2017 and January 2018. The number of nurses participating in the research is 300. The data were evaluated in SPSS 21 and AMOS 22 programs. The scale is statistically valid and reliable. Cronbach Alpha 0.95 of the scale, which was applied statistically after content and content validity, construct validity and reliability analysis, were applied. It has four sub-dimensions (Information, Cognition, Participation and Interest) and includes 44 items. The policy guides many important issues such as education, management, expertise, implementation and professionalization of nurses. International literature on nursing and policy issues are qualitative, there is no quantitative study. So it is the first measurement tool. The scale is thought to be effective in measuring the political sensitivity of nurses and international nursing literature.
\end{abstract}

Key Words: Scale Development, Nurses, Political, Awareness

Türkiye'de Hemşirelerde Politik Duyarlılık Ölçeği ve Psikometrik Testlerin Geliştirilmesi: Metodolojik Bir Çalışma

$\ddot{O} z$

$\mathrm{Bu}$ çalışma, hemşireler için bir Politik Duyarlılık Ölçeği geliştirmek ve geçerliliğini ve güvenirliğini ortaya koymak amacıyla gerçekleştirilmiştir. Bu çalışma metodolojik tasarımda hazırlanmışır. Veriler Haziran 2017 ile Ocak 2018 arasında toplanmıştır. Araştırmaya katılan hemşire sayısı 300'dür. Veriler SPSS 21 ve AMOS 22 programlarında değerlendirilmiştir. Ölçek istatistiksel olarak geçerli ve güvenilirdir. İçerik ve kapsam geçerliliği, yapı geçerliliği ve güvenirlik analizleri sonrasında istatiksel açıdan uyguluğu sağlanan ölçeğin Cronbach Alpha 0.95'dir. Dört alt boyutu vardır (Bilgi, Biliş, Katılım ve İlgi Alanı) ve 44 madde içermektedir. Politika, hemşirelerin eğitimi, yönetimi, uzmanlığ1, uygulanması ve profesyonelleştirilmesi gibi birçok önemli konuya rehberlik etmektedir. Hemşirelik ve politika konularında uluslararası literatür niteldir, nicel bir çalışma yoktur. Bu yüzden illk ölçüm aracıdır. Ölçeğin, hemşirelerin ve uluslararası hemşirelik literatüründeki politik duyarlılığın ölçülmesinde etkili olacağı düşünülmektedir.

Anahtar Kelimeler: Ölçek Geliştirme, Hemşireler, Politik, Duyarlılık

\section{Atıf İçin / Please Cite As:}

Kuşcu-Karatepe, H., \& Yıldırım, A. (2020). The development of a political awareness scale and psychometric testing on nurses in Turkey: A methodological study. Manas Sosyal Arasttrmalar Dergisi, 9(4), 2418-2429.

Geliş Tarihi / Received Date: 21.04.2020

Kabul Tarihi / Accepted Date: 27.07.2020

\footnotetext{
${ }^{1}$ This study is derived from the $\mathrm{PhD}$ thesis titled Determining the Relationship between Political Awareness and Perception of Organizational Democracy in Nurses completed by Hilal Kuşcu Karatepe at Istanbul University-Cerrahpaşa Graduate Education Institute.

2 (Corresponding Author) Assistant Professor - Osmaniye Korkut Ata University Faculty of Health Sciences, Department of Nursing, hkuscukaratepe@osmaniye.edu.tr ORCID: 0000-0001-9237-2714

3 Prof. Dr. - Istanbul University Florence Nightingale Faculty of Nursing, Department of Nursing, aytolany@istanbul.edu.tr ORCID: 0000-0002-0475-6695
} 


\section{Introduction}

Policy is a convincing feature of contemporary health care in all areas. Policies determine the health care delivery, presentation models and role and scope of health professionals. Policies give direction to many things as from the clothing of health workers (Bearman et al., 2014, p. 109) to large-scale system reform (Zon et al., 2016, p. 263).

Historically, nurses have had limited involvement in policy and political decisions that affect health service delivery (Juma, Edwards, \& Spitzer, 2014, p. 1). Nurses are far from policy, even though they perform their professional roles in line with health policies. Nurses are often reluctant to policy what they think of as politics (Yildirlm, 2018, p. 3). Literature further reveals several reasons for nurses under engagement in policy including lack of awareness of policy related issues and processes. The complexity and dynamism of health policies, lack of consciousness, information, interest opportunity, time and resources for participation, inadequate skills (Brokaw, 2016, p. 2), financial shortfall and family obligations (Kung, Windle, \& Walker, 2014, p. 1709), failure to provide sufficient support for nurses to produce the necessary evidence to influence health policy (Brokaw, 2016, p. 2), heavy workload, often feeling powerless, gender issues, oppressive images, management ineffectiveness and incompetence, lack of knowledge of the necessity to participate in policies, political awareness, policy development skills, the notion that political participation will not be of any benefit (Kunaviktikul, 2014, p. 2), perception of exclusion from politics, not seeing themselves as part of the political process, views not being in sufficient numbers and power to make a difference (Brokaw, 2016, p. 2; Rakuom, 2010, p. 8) may be the main ones.

But nurses have the potential to change their health policies by improving their political awareness. Today, nursing is the world's largest and strongest candidate for healthcare, with only about 4 million in the United States and around 35 million in the world (Yildirim, 2018, p. 4). At the core of the nursing profession are individual and professional values, abilities, beliefs and practices that are able to change health policies for the benefit of the patient (Juma et al., 2014, p. 7). They are strategically positioned to make significant improvements in the health services of a country. Nurses have the power to identify needs and problems, allocate resources, control their own work, influence people (Avolio, 2014, p. 14). It is also described some of the personal abilities of nurses with political awareness: Nurses are ambitious, broad perspective, excellent negotiator, communicator, problem solver and good team players. The need for nurses in health care settings to manage difficult personalities, neutralize potentially unstable situations and manage conflicts is indescribable. Nurses have the potential to be effective by becoming more active in addressing health policy that will increase quality patient care. Also, nurses have the necessary skills to analyze, critically think and analyze health policy information (Kuşcu Karatepe, 2019, p. 17). On the other hand, among the public, nurses are the appropriate representative and one of the most trusted professionals to advocate for health. Today, nurses are expected to be able to lead as an agent of change for patients, to take on roles such as advocacy, cooperation, policy change and community responsiveness (Avolio, 2014, p. 4). Nurses' fulfillment of their political roles is one of the most effective strategies to improve the health and welfare of the population. Nurses can influence decision-makers by using their political competencies in a wide range of social networks including various civil society organizations and organizations to change disease patterns, aging societies, global health threats, health reforms and inequalities, health workforce imbalances (Arabi, Rafil, Cheraghi, \& Ghiyasvandian, 2014, p. 317). In addition, nurses' engagement with legal regulations affecting their patients is a moral and professional obligation. When nurses influence the policy that improves the delivery of health services, they will ultimately fulfill their obligation to defend their patients (Brokaw, 2016, p. 3). Also, policy acts as a regulatory system in terms of providing professional identity to the nursing and the methods of employing the members of the nursing. Many aspects of the nursing profession are of political nature and are influenced by a large number of policies. Policy has a significant impact on the direction of nursing practice, education, management, expertise, and professionalization (Yildırım, 2014, p. 32). Therefore, policy is one of the most important factors that affect every kind of process starting from the definition of nursing (Esenay, 2017, p. 98).

It's noteworthy that the literature does not elaborate on these areas, while nurses have a large area of study on political regulations (Ditlopi, Blaauw, \& Penn-Kekana, 2014, p. 2). Most existing international literature linking nursing and policy is concerned with the absence of nurses in health policy processes Juma et al., 2014, p. 5). All of the current international literature inking nursing and policy are qualitative. Quantitative study wasn't found, so it is the first measuring tool. It is thought that this scale will be useful in assessing and improving nurses' awareness in the political arena. 


\section{Method}

This study is a methodological study. It was carried out as a two-phase study, as conceptualization and analysis. Statistical methods are shown in Table 1.

Table 1. Statistical methods used

\begin{tabular}{ll}
\hline Quality Examined & Statistical Methods \\
\hline Validity Analyses & Content Validity (Calculating CVR and CVI using Lawshe's method) \\
& Structure Validity (Explanatory Factor Analysis, Confirmatory Factor Analysis) \\
& Item analysis (Pearson Correlation) \\
& Cronbach Alpha Internal Consistency Coefficient \\
Reliability analyses & Spearman-Brown Internal Consistency Coefficient \\
& Guttman Internal Consistency Coefficient \\
Time Invariance Analysis & Pearson Correlation Coefficient \\
(Test-Retest Application) & \\
\hline
\end{tabular}

\section{Phases}

\section{Phase one: Conceptualization}

At this stage, the field paper on the concept of policy has been scanned. The scales of attitudes, awareness and sensitivity in different areas were studied by researchers. In addition, many qualitative studies on national and international policy; field literature containing the concepts directly and indirectly related to policy were used and a pool of material was prepared in line with the knowledge and experiences of its researchers. The book, name is "Introduction to Policy Science" by Kapani (2015, p. 23) especially used. Within the framework of this information, a large number of positive and negative statements about political awareness were written randomly in accordance with the literature, taking into account the characteristics of a measuring instrument. When creating substances, it is considered to be simple, short and clear. Its expressions have been controlled by a linguist specializing in the field. The substance pool consists of 86 substances. 5-gauge Likert type scale scoring was used. Scale scoring $1=$ disagree at all, $2=$ agree little, $3=$ agree, $4=$ fairly agree, $5=$ totally agree. Points $1-2$ were used to indicate non-participation in the item in descending order and points 3-5 were used to indicate non-participation in the item in ascending order.

\section{Phase two: Validity and Reliability Analysis}

The scale of political awareness validity was confirmed in three main steps. The first was achieved through academics who specialized in the field of surface and content validity. Second, psychometric properties were evaluated using cross-sectional data used to make EFA. Third, the resulting psychometric structure was verified using confirmatory factor analysis.

The scale of political awareness reliability was confirmed in two main steps. Item analysis, Cronbach Alpha, Spearman-Brown and Guttman internal consistency coefficients were examined separately for each sub-dimension in the first. Then the test-retest analysis was examined with the correlation coefficient of the Pearson Correlation.

\section{Surface and Content Validation}

For surface validation, the researchers tested the intelligibility, nature, directive, usefulness, suitability for the purpose of each of the pool items that benefited from the views of their close-circle colleagues. Before the introduction of general applications, an expert in the field of Turkish Language and Literature (lecturer) opinion was also taken, depending on the fact that there may be any unnoticed spelling, expression or form problems on the pool items created.

For content validation, to receive the opinions of experts, we sent 15 experts an 'Expert Evaluation Form' via e-mail. The experts reported their views for each item as "appropriate", "appropriate, but needs minor changes," and "not appropriate." There have been feedback from 12 experts in two months.The 12 experts who made the assessment are academicians working in Public Administration, Nursing Management, Teaching Nursing and Internal Medicine Nursing department at universities in Istanbul, Izmir, Konya, Antalya, Samsun, Bolu and Osmaniye province of Turkey. Content validity ratios (CVR) were calculated using Lawshe's method. In the evaluation, the minimum CVR criteria, determined by Veneziano and Hooper (1997, p. 68) were used (Cited by Ayre, \& Scally, 2014, p. 82). 


\section{Evaluation of Psychometric Properties}

Eligible nurses were informed about the purpose of the study before a written consent form was obtained. The data collection tool covers the socio- demographics of nurses (gender, age, marital status, working environment and years of experience) and the scale version of political awareness after the surface and content validity phase.

\section{Explanatory Factor Analysis (EFA)}

According to the recommendations of Watkins (2018, p. 227), which recommends registering at least five participants for each item of the scale for the EFA, the sample size required for the scale study belongs to 220 nurses (there are a total of 44 items on the political awareness scale). Given the number of nurses reached in the research universe and the participation of nurses on the basis of volunteering, the final number of the sample was determined as 300 .

Before starting factor analysis, Kaiser-Meyer-Olkin (KMO) and Barlett Sphericity tests were performed to determine the suitability of sample size for factor analysis. EFA was used to analyze the eigen values and to select the number of factors to be deduced as a result of the analysis. For a variable to be included in a factor group, the factor load based on at least 0.40 (Jovanović, Milijić, \& Stojanović, 2017, p. 18).

\section{Confirmatory Factor Analysis (CFA)}

If there is an effort to develop a scale, the first to be applied is the EFA, then the CFA, which predicts the confirmation of this new factor structure being discovered. CFA is a process for creating a hidden variable (factor) based on the variables observed through a pre-generated model (Pan, Ip, \& Dubé, 2017, p. 689). After exploratory factor analysis, CFA analysis was performed to test the accuracy of the four-factor scale structure. The index criteria required for confirmatory factor analysis (Reas, Lindvall, Wonderlich, Syversen, \& Lundin, 2018, p. 208) are confirmed by AMOS 22 programs.

\section{Reliability}

In order to evaluate the reliability of the scale; item analysis, Cronbach Alpha, Spearman-Brown, Guttman internal consistency coefficients and test-retest correlations were used (Latner, Mond, Kelly, Haynes, \& Hay, 2014, p. 651). Test-retest reliability to determine the in variance criterion over time (Pavia et al., 2014, p. 5). In this study 30 nurses selected for the test-retest reliability. It is recommended by the literature to recruit at least 30 individuals for test-retest analysis. Two weeks after the first application, the same people were visited for the second time and they filled out the forms again (Latner et al., 2014, p. 650).

\section{Sample}

The universe of the research consists of 402 nurses working in one Health Research and Practice Hospital and two private hospitals in Turkey Hatay province between June 2017-January 2018. The study was conducted by reaching the maximum number of nurses available for planned hospitals without resorting to any sampling method. The question pool is composed of 86 items and the draft scale form after the expert opinion is composed of 55 items. The number of samples is 300 . In this case, sampling was reached at approximately 6 times the size of the number of substances. The sample size is $N=50$ very weak, $\mathrm{N}=100$ weak, $\mathrm{N}=200$ medium, N=300 Good, N=500 very good, N=1000 excellent (Latner et al., 2014, p. 651; Speidel, Orman1, Shi, \& Myers, 2019, p. 1325). Finally, of the 372 nurses sampled, 40 did not agree to participate in the study; of the 332 , there was a survey return. It was decided that 32 surveys should be excluded from analysis due to the items left blank on the scale during the control of the surveys. The universe welcome ratio of the sample is $75 \%(\mathrm{~N}=300)$.

\section{Instrument}

Scale has 4 sub-dimensions and 44 items. Level of knowledge is measured by; 3., 4., 5., 8., 10., 13. , 14., 16., 17., 19., 21., 27., 28., 31., 38., 39., 43. items, level of cognition; 1., 11., 12., 15., 18., 30., 33., 34., 35., 37., 40., 46. items, level of participation; 9., 22., 23., 24., 25., 47., 49., 50., 51. items, level of interest; 45., 48., 52., 53., 54., 55. items. All items are scored flat. The score taken from the scale is between 44-220. The higher the score, the higher the level of political awareness. Lower size score ranges; it is 17-85 for the subdimension of knowledge, 12-60 for the subdimension of cognition, 9-45 for the subdimension of participation and 6-30 for the subdimension of interest. As scores increase, levels of knowledge, cognition, participation and interest in politics will increase. 


\section{Data Collection}

The data collection process was conducted by the researchers. In the institutions where permission has been obtained, information about the research has been given and it has been stated that it can be completed in about 10 minutes by introducing the scale and forms to be filled out. It is specifically stated to the nurses that the principle of volunteerism is essential in the study, that they can withdraw from the study at any time and that they will not face any coercion or sanctions. The nurses were given their oral and written consent (in the questionnaire) after they were told the purpose of the study, the method of application and the expectations. Some of the forms were given and receivedfrom the nurses on the same day. Another part was filled with face-to-face interview technique by the researcher themselves. For nondelivery forms, departments have been given a maximum of 7 days, and have been revisited and delivered at the end of the period.

\section{Ethical Considerations}

Ethics committee of a public university was approved (09.03.2017/59754796-050.99/) for this research. The research was conducted in accordance with international ethical principles and the legal requirements of Turkey for non-interventional studies. The nurses involved in the study were informed about the purpose and methodology of the study and written consent was obtained from all of them.

\section{Results}

\section{The socio-demographic results}

Descriptive statistics were used to determine the socio-demographic characteristics of nurses. At the same time, normality was determined in Skewness and Kurtosis assessments where the relevant variables on the scale were expressed using mean and standard deviation (SD). The socio-demographic characteristics of the nurses are shown in Table 2. $69 \%$ of the nurses were female, $72.3 \%$ were single, $49 \%$ had an undergraduate degree; $85.3 \%$ worked on the weekends, $68.7 \%$ worked in private hospitals, $42 \%$ worked in intensive care; and $86.3 \%$ were not members of any professional unions. The average age was $24.91 \pm 5.167$, the average monthly income (TL) was TL2098.36 \pm TL662.200, the mean number of years worked was $4.46 \pm 4.004$, the mean number of years worked in the same institution was $2.81 \pm 2.436$ and the mean number of hours worked weekly was $47.04 \pm 6.554$.

Table 2. Sociodemographic Characteristics of the Nurses $(N=300)$

\begin{tabular}{|c|c|c|c|}
\hline \multicolumn{2}{|c|}{ Social-Demographic Variables } & $\mathbf{N}$ & $\%$ \\
\hline \multirow{2}{*}{ Gender } & Female & 207 & 69 \\
\hline & Male & 93 & 31 \\
\hline \multirow{2}{*}{ Marital status } & Married & 83 & 27.7 \\
\hline & Single & 217 & 72.3 \\
\hline \multirow{4}{*}{ Education } & High school & 113 & 37.7 \\
\hline & Associate degree & 33 & 11 \\
\hline & Undergraduate & 147 & 49 \\
\hline & Master's degree & 7 & 2.3 \\
\hline \multirow{2}{*}{ Work on weekends } & Yes & 256 & 85.3 \\
\hline & No & 44 & 14.7 \\
\hline \multirow{2}{*}{ Institution } & Private hospital & 206 & 68.7 \\
\hline & State hospital & 94 & 31.3 \\
\hline \multirow{5}{*}{ Department } & Clinic & 21 & 7 \\
\hline & Intensive care & 126 & 42 \\
\hline & Inpatient care units & 107 & 35.7 \\
\hline & Emergency department & 30 & 10 \\
\hline & Administration & 16 & 5.3 \\
\hline \multirow{2}{*}{ Member of a union } & Yes & 41 & 13.7 \\
\hline & No & 259 & 86.3 \\
\hline Age (mean) & $24.91 \pm 5.167$ & Experience & $4.46 \pm 4.004$ \\
\hline Monthly income (TL) & $2098.36 \pm 662.200$ & $\begin{array}{l}\text { Work period in the same institution (year) } \\
\text { Weekly working hours }\end{array}$ & $\begin{array}{r}2.81 \pm 2.436 \\
47.04 \pm 6.554\end{array}$ \\
\hline
\end{tabular}

\section{Surface and Content Validity}

Opinions of the researchers, the researchers' colleagues in the immediate vicinity and an expert (a lecturer) in the field of Turkish Language and Literature were collected. The surface validity of the scale 
was ensured. The Content Validity Ratios (CVR) was 0.56 for 12 experts. A total of 42 items were excluded from the study whose CVR had a negative value, " 0 ", or lower than 0.56 . The Content Validity Index (CVI) of the remaining 44 items and 11 items which were corrected, divided and added based on the experts' suggestions, was found to be 0.83 overall, since the draft scale was not divided into subgroups. Because CVI $>$ CVR $(0.83>0.56)$, the content validity of the whole scale was statistically significant $(p<0.05)$.

\section{Exploratory Factor Analysis (EFA)}

300 nurses were sampled to take part in the assessment in exploring the psychometric properties of the Political Awareness Scale through the analysis. Before factor analysis was conducted, Kaiser-MeyerOlkin (KMO) and Bartlett Sphericity tests were performed to determine whether the sample size was adequate for factor analysis. The KMO measure of sampling adequacy of the scale was 0.874 . Bartlett's Test of Sphericity was calculated by $\chi^{2} / \mathrm{df}$ and was found to be $37019.273 / 946(p=0.000)$.

In the EFA the sub-cutoff point was 0.40 . The factor load value of 11 items remained below 0.40 . Factor loads of the draft scale range from 0.911 to 0.958 for factor 1; from 0.562 to 0.953 for factor 2 to 0.926 to 0.963 for factor 3 and from 0.928 to 0.950 for factor. The eigenvalue coefficient is taken into consideration in sizing the items whose factor load is over 0.40. Four breakpoints were found in determining the factors. The total variance of the draft scale was determined to be $91.92 \%$. The rate of variance described for the first factor is $35.92 \%$; for the second factor is $23.36 \%$; for the third factor is $19.67 \%$ and for the fourth factor is $12.97 \%$.

The varimax rotation method was used for factor rotation. The factor rotation showed that subdimension 1 of the scale consisted of 17 items $(3,4,5,8,10,13,14,16,17,19,21,27,28,31,38,39$ and 43), subdimension 2 consisted of 12 items $(1,11,12,15,18,30,33,34,35,37,40$ and 46), subdimension 3 consisted of 9 items (9, 22, 23, 24, 25, 47, 49, 50 and 51) and subdimension 4 consisted of 6 items (45, 48, 52, 53, 54 and 55). As a result of the EFA, the Political Awareness Scale consisting of 4 dimensions and 44 items was developed. The names given to the dimensions are made by taking into account the content of the items. In dimension 1, statements measuring knowledge assessed the level of "knowledge"; in dimension 2, statements related to the level of general knowledge assessed "cognition"; in dimension 3, statements measuring participation in politics assessed "participation" and in dimension 4, statements related to using energy, time and resources for politics measured the level of "interest". Concepts related to politics were used in naming the dimensions.

\section{Confirmatory Factor Analysis}

Confirmatory Factor Analysis, the second step of the construct validity test of the four-factor structure revealed in the exploratory factor analysis, was conducted. For each index, acceptable cut-off values proposed by Reas, Lindvall, Wonderlich, Syversen, \& Lundin (2018, p. 209) were taken into account. The CFA analysis was: $\chi 2 / \mathrm{df}=1.92$, RMSEA $=0.06, \mathrm{RMR}=0.08, \mathrm{IFI}=0.92, \mathrm{CFI}=0.92, \mathrm{GFI}=0.90$ and AGFI $=0.87$. The fault covariance was set between e 3 and e5, e12 and e13, and e41 and e42 (Figure 2). 


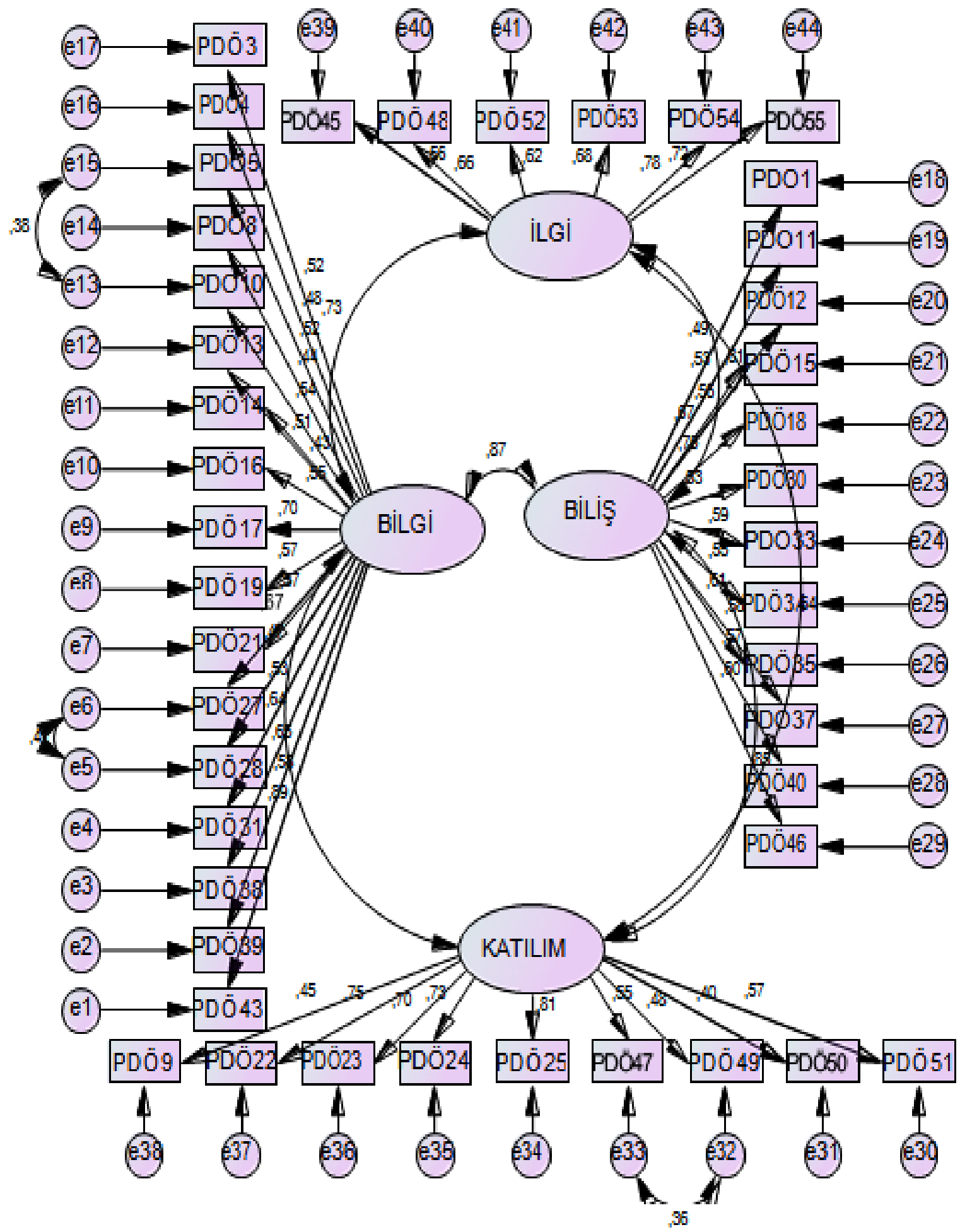

Figure 2. Political Awareness Scale CFA Chart (Obtained From The Authors' Research Data)

\section{Reliability}

Reliability analysis was conducted using item analysis, Cronbach Alpha, Spearman-Brown, Guttman internal consistency coefficients and test-retest correlations. In examining the item total score correlations of the 44 items for the reliability study of the Political Awareness Scale, correlation coefficients of these items ranged between $r=0.505$ and $0.963(p<0.001)$. Internal consistency coefficients of the Political Awareness Scale were 0.958 for Cronbach Alpha, 0.894 for Spearman-Brown and 0.865 for Guttman. Table 3 shows item analysis and internal consistency coefficients related to the subdimensions of the scale $(p<0.01)$. Scale-compliant test-retest reliability is achieved $(p<0.001)$. 
Table 3. Item Analysis Results and Internal Consistency Coefficients ( $N=300)$

\begin{tabular}{|c|c|c|c|}
\hline Scale Sub-Dimensions & $\begin{array}{c}\text { Item total score } \\
\text { Correlation* }\end{array}$ & $\begin{array}{c}\text { Cronbach Alpha } \\
\text { When an item was excluded }\end{array}$ & \\
\hline \multicolumn{4}{|l|}{ Knowledge subdimension } \\
\hline Item 3 & .975 & .973 & \\
\hline Item 4 & .941 & .974 & \\
\hline Item 5 & .966 & .973 & \\
\hline Item 8 & .954 & .973 & Cronbach's \\
\hline Item 10 & .965 & .973 & Alpha 0.976 \\
\hline Item 13 & .951 & .973 & Spearman- \\
\hline Item 14 & .947 & .974 & Brown* 0.978 \\
\hline Item 16 & .969 & .973 & Guttman* 0.944 \\
\hline Item 17 & .954 & .973 & \\
\hline Item 19 & .966 & .973 & \\
\hline Item 21 & .957 & .973 & \\
\hline Item 27 & .954 & .973 & \\
\hline Item 28 & .978 & .973 & \\
\hline Item 31 & .919 & .995 & \\
\hline Item 38 & .967 & .973 & \\
\hline Item 39 & .965 & .973 & \\
\hline Item 43 & .956 & .973 & \\
\hline \multicolumn{4}{|l|}{ Cognition subdimension } \\
\hline Item 1 & .643 & .834 & \\
\hline Item 11 & .943 & .812 & \\
\hline Item 12 & .943 & .812 & \\
\hline Item 15 & .943 & .812 & Cronbach's \\
\hline Item 18 & .942 & .812 & Alpha 0.854 \\
\hline Item 30 & .879 & .923 & Spearman- \\
\hline Item 33 & .944 & .928 & Brown* 0.968 \\
\hline Item 34 & .818 & .821 & Guttman*0.968 \\
\hline Item 35 & .918 & .813 & \\
\hline Item 37 & .918 & .814 & \\
\hline Item 40 & .946 & .811 & \\
\hline Item 46 & .948 & .810 & \\
\hline \multicolumn{4}{|c|}{ Participation subdimension } \\
\hline Item 9 & .962 & .971 & \\
\hline Item 22 & .964 & .971 & Cronbach's \\
\hline Item 23 & .968 & .970 & Alpha 0.972 \\
\hline Item 24 & .967 & .970 & Spearman- \\
\hline Item 25 & .965 & .970 & Brown* 0.968 \\
\hline Item 47 & .952 & .971 & Guttman* 0.968 \\
\hline Item 49 & .956 & .971 & \\
\hline Item 50 & .948 & .971 & \\
\hline Item 51 & .942 & .971 & \\
\hline \multicolumn{4}{|l|}{ Interest subdimension } \\
\hline Item 45 & .970 & .986 & Cronbach's \\
\hline Item 48 & .960 & .987 & Alpha 0.989 \\
\hline Item 52 & .951 & .988 & Spearman- \\
\hline Item 53 & .964 & .986 & Brown* 0.990 \\
\hline Item 54 & .965 & .986 & Guttman* 0.990 \\
\hline Item 55 & .960 & .987 & \\
\hline
\end{tabular}

As a result, in the finalized scale with four sub-dimensions and 44 items, items $3,4,5,8,10,13,14$, 16, 17, 19, 21, 27, 28, 31, 38, 39 and 43 assessed knowledge level; items 1, 11, 12, 15, 18, 30, 33, 34, 35, 37, 40 and 46 assessed cognition level; items 9, 22, 23, 24, 25, 47, 49, 50 and 51 assessed participation and items 45, 48, 52, 53, 54 and 55 assessed interest. All items were scored directly. The score obtained from the scale ranges between 44-220. As the score increases, the level of political awareness increases. Ranges of subdimension scores were: 17-85 for knowledge, 12-60 for cognition, 9-45 for participation and 6-30 
for interest. As the scores increase, levels of knowledge, cognition, participation and interest in politics increase. The Political Awareness Scale is a statistically valid and reliable tool.

\section{Discussion}

The Political Awareness Scale estimates of reliability and validity is acceptable. It is found compatible with the literature (Forney, Bodell, \& Haedt-Matt, 2016, p. 655). First of the validity step; surface and content validity was obtained. It estimates that is acceptable. EFA which is the next step of the political awareness scale, is one of the most used methods to evaluate whether items in the scale are collected under different dimensions (Esin, 2014, p. 202). In this study, it was found that 44 items were grouped under four factors: knowledge, cognition, participation and interest. Also the Explained Variance is accepted as an indicator of how well the related concept or structure is measured. In EFA; the Total Variance described is recommended to be between $40 \%$ and $60 \%$ in the literature (Reas, Lindvall, Wonderlich, Syversen, \& Lundin, 2018, p. 210). In this study Total Variance explained is $91.92 \%$ and it can be evidence of acceptable validity. After EFA, CFA was performed. Confirmatory factor analysis is performed to test the validation of a predetermined structure. As a result of the analysis, goodness of fit indices are used to show how suitable the tested model is to the sample data (Henseler \& Sarstedt, 2013, p. 567).

The scale is acceptable by taking into consideration the index values and it was found to be sufficient in the literature (Reas, Lindvall, Wonderlich, Syversen, \& Lundin, 2018, p. 210) Item analysis is the first for reliability. Item analysis determines at what level the elements of the measurement tool are related to the whole measurement tool (Forney et al., 2016, p. 656). A high correlation coefficient obtained for a given element indicates that the element has a high correlation with the measured theoretical structure and that the element is effective and sufficient to measure the intended behavior (Speidel et al., 2019, p. 1327). It is recommended that the total score correlation coefficient of the items is above 0.30. According the analysis of Item Total Score Correlations of 44 items of scale, they are ranged between $r=0.505$ and 0.963 and it is acceptable with a positive and statistically significant relationship. It can be estimate that the correlation coefficient values of the scale are high when compared with the literature. Internal consistency is the second stage of reliability and is the state of homogeneity between questions thought to measure a specific area (Forney et al., 2016, p. 660). The Cronbach Alpha coefficient used to measure this varies from 0 to 1 . If the Cronbach Alpha coefficient is $0.60-0.80$, the scale is considered to be highly reliable (Arip, Rashid, Ahmad, \& Husin, 2018, p. 405). It was found to be 0.958. So it estimates acceptable reliability. The Spearman-Brown and Guttman coefficients estimate quite high and consistent with the literature. The correlation coefficient between test-retest scores in the scales is expected to be at least 0.70 (Esin, 2014, p. 210). In the test-retest reliability study conducted at two-week intervals, the correlations between the two applications estimates quite high (0.98). There was a positive, strong and statistically significant relationship between the two measurement scores $(p<0.001)$. This result estimatesthat the scale measures the same structure decisively.

Political Awareness Scale overall score average was above average (138.39 \pm 26.56$)$. The highest lower dimension score average is "knowledge" (52.28 \pm 14.50$)$ and the lowest is "interest" (16.22 \pm 6.54$)$. This difference indicates that nurses are unconcerned with the policy but, despite this, have some way of knowing about the issues. It can be thought that they have gained their knowledge from the media or everyday chat environments by including the themes related to the subject such as health policy, profession, professionalization concept in addition to the Nursing Management Course at the undergraduate level and often being brought to the agenda in academic settings. Research in field literature has found studies showing that nurse managers have a high level of political knowledge (Ditlopi et al., 2014, p. 2). There are also studies showing that courses given to nursing students increase political interest (Hart, 2016, p. 11; Carnago, Eaton, Lanier, \& Deveneau, 2018, p. 3). Shariff (2014, p. 8) and Rains and Corroll (2000, p. 38, Cited by Ahmed, \& El-Hosany, 2018, p. 12)'s studies show that if nurses' level of knowledge about health policy increases, their participation increases. According to the study of Sarnkwawkum and Oumtanee (2017, p. 5), the presence of people interested in politics around nurses, the sense of being able to intervene in jobs that don't go their way and respond to needs, the invitations of politicians can elevate nurses' political awareness.

Lack of political participation, knowledge, skills, support and resources and negative nursing image are major obstacles to political awareness (Ahmed, \& El-Hosany, 2018, p. 2). The field article states that nurses have hierarchical barriers (Juma et al., 2014, p. 7; Roche, 2015, p. 530). It is also noted that doctors 
have a higher political predisposition in field study and another study found that nurses are mostly invisible and that doctors in particular in Kenya, Uganda and Tanzania are more active in nursing processes (Takian, Rashidian, \& Doshmangir, 2015, p. 10; Ditlopi et al., 2014, p. 7). In Thailand according a study was measured nurses' participation in the political process, the majority of nurses are highly knowledgeable in all aspects of national health policy development, despite being a quarter of this level are willing to participate in development of National Health Policy nurse managers who work only in a hospital where less than fifty percent per cent of the institution they were involved in the development of policies. For participation in the development of health policies, Shariff and Potgieter (2012, p. 4) have stated that support, encouragement and inspiration from a good role model are essential.

\section{Conclusion}

This study developed and validated a 44-item Political Awareness Scale measure political awareness of nurses. It is a statistically valid and reliable tool. This scale was chosen to be developed since the researchers had found no measurement tool in previous studies for determining the level of political awareness of nurses. The newly developed political awareness scale can be used in nursing education, management, expertise, practice and professionalization. In this context, it can be suggested that the Political Awareness Scale be used in different institutions and with different professional groups as well as in studies that can be conducted with nurses.

\section{Ethical Declaration}

In the writing process of the study titled "The Development of a Political Awareness Scale and Psychometric Testing on Nurses in Turkey: A Methodological Study", there were followed the scientific, ethical and the citation rules; was not made any falsification on the collected data and this study was not sent to any other academic media for evaluation.

\section{References}

Ahmed, H. S., \& El-Hosany, E. W. (2018). Factors facilitate head nurses' policy development and autonomy in decision making. International Journal of Nursing Didactics, 8(2), 1-14.

Arabi, A., Rafil, F., Cheraghi, M. A. \& Ghiyasvandian, S. (2014). Nurses' policy influence: A concept analysis İran. Journal of Midwifery Research, 19(3), 315-322.

Arip, M. A. S. M., Rashid, N. A., Ahmad, S. H., \& Husin, N. S. (2018). The Development, Validity and Reliability of Higher-Order Thinking Skills - Peer Appraisal Inventory (HOTS-PA). International Journal of Academic Research in Business and Social Sciencest, 8(3), 395-409.

Avolio, C. D. (2014). Political Advocacy: Beliefs and Practices of Registered Nurses. Electronic Theses and Dissertations. University of Windsor: Electronic Theses and Dissertations.

Ayre, C., \& Scally A. J. (2014) Critical values for Lawshe's content validity ratio: revisitingt he original methods of calculation. Measurementand Evaluation in Counselingand Development, 47(1), 79-86.

Bearman, G., Bryant, K., Leekha, S., Mayer, J., Munoz-Price, L.S., Murthy, R., \& White, J. (2014). Healthcare personnel attire in non-operating-room settings. Infection Control and Hospital Epidemiology 35, 107-121.

Brokaw, J. J. (2016). The Nursing Profession's Potential Impact on Policy and Politics; 1-3.

Carnago, L., Eaton, K. M., Lanier, B. B., \& Deveneau, K. L. (2018). From Practical to Powerful: How a Nursing Student Health Policy Fellowship Transformed my Political, Professional and Patient Advocacy. HSOA Journal of Practicaland Professional Nursing, 2(1), 1-6.

Ditlopi, P., Blaauw, D. \& Penn-Kekana, L. (2014). Contestations and complexities of nurses' participation in policymaking in South Africa. Glob Health Action. 7, 1-14.

Esenay, F. I. (2017). Health policies and nursing. Ankara University Open Lecture Publications. (Original work published in Turkish).

Esin, M. N. (2014). Research in nursing. Data collection methods and tools, reliability and validity of data collection tools. Istanbul: Nobel Medical Bookstore. (Original work published in Turkish).

Forney, J. K., Bodell, L. P., \& Haedt-Matt, A. A. (2016). The incremental validity of the episode size criterion in bingeeating definitions: An examination in women with purging syndromes. Int J Eat Disord., 49(7), 651-662.

Hart, L. (2016). The political astuteness of nurse practitioners following a successful legislative journey. Date Accessed: 01.12.2019, https://mospace.umsystem.edu/xmlui/bitstream/handle/10355/49150/HartPolitical\%20Astuteness $\% 20$ of $\% 2$ 0Nurse $\% 20$ Practitioners $\% 20$.pdf?sequence $=1 \&$ is Allowed $=\mathrm{y}$

Henseler, J., \& Sarstedt, M. (2013). Goodness-of-fit indices for partial least squares path modeling. Comput Stat, 28, 565-580.

Jovanović, I., Milijić, N., \& Stojanović, A. (2017). Modelling of knowledge management factors in project organizations. European Project Management Journal, 7(1), 13-23.

Juma, A. P., Edwards, N. and Spitzer, D. D. (2014). Kenyan nurses involvement in national policy development processes. Hindawi Publishing Corporation Nursing Research and Practice, 10, 1-11. 
Kapani, M. (2015). Politika bilimine giris. Ankara: Bilgi Yayınevi.

Kunaviktikul, W. (2014). Moving towards the greater involvement of nurses in policy development. Int Nurs Rev., 61(1), 1-2.

Kung, L., Windle, M. C., \& Walker, N. (2014). The effect of an exogenous protease on the fermentation and nutritive value of high-moisture corn. Journal of Dairy Science, 97(3), 1707-1712.

Kuşcu Karatepe, H. (2019). Determination of the relationship between political sensitivity and organizational Democracy Perception in nurses (PhD Thesis). Istanbul University-Cerrahpasa Graduate School of Education, Department Of Nursing Management. Istanbul. (Original work published in Turkish).

Latner, J. D., Mond, J. M., Kelly, M. C., Haynes, S. N., \& Hay, P. J. (2014). The loss of control over eating scale: Development and psychometric evaluation. Int J Eat Disord., 47(6), 647-59.

Pan, J., Ip, E. H., \& Dubé, L. (2017). An alternative to post hoc model modification in confirmatory factor analysis: The Bayesian lasso. Psychological methods, 22(4), 687-704.

Pavia, E. C., Barroso, M. E., Carneseca, C. E., Souza, P., Santos, T., Lopez, V. R., \& Pavia, S. B. (2014). A critical analysis of test-retest reliability in instrument validation studies of cancer patients under palliative care: A systematic review. BMC Medical Research Methodology, 14(1), 1-10.

Rains, J. W., \& Carroll, K. (2000) The effect of health policy education on self-perceived political competence of graduate nursing students. The Journal of Nursing Education 39(1), 37-40.

Rakuom, C. (2010). Nursing human resources in Kenya: A case study, international centre for buman resources in nursing. Date Accessed: 01.12.2019 http://www.ichrn.com/publications/casestudies/ICHRN Kenya CaseStudy.pdf.

Reas, D. L., Lindvall Dahlgren, C., Wonderlich, J., Syversen, G., \& Lundin, K. I. (2018). Confirmatory factor analysis and psychometric properties of the Norwegian version of the repetitive eating questionnaire: further evidence for two distinct subtypes of grazing behaviour. Eur Eat Disord Rev., 27(2), 205-211.

Roche, M. (2015). Testing the Nursing Worklife Model in Canada and Australia: A multi-group comparison study. Int J Nurs Stud., 52(2), 525-34. https://doi.org/10.1016/j.ijnurstu.2014.10.016

Sarnkwawkum, P., \& Oumtanee, A. (2017). Being nurseepoliticians in Thailand: A phenomenological Research. Kasetsart Journal of Social Sciences, 1-6.

Shariff, N. (2014). Factors that act as facilitators and barriers to nurse leaders' participation in health policy development. BMC Nursing, 13, 20-26. https://doi.org/10.1186/1472695513-20

Shariff, N., \& Potgieter, E. (2012). Extent of East-African nurse leaders' participation in health policy development. Nurs Res Pract. 7, 1-8. http://dx.doi.org/10.1155/2012/504697

Speidel, L., Forest, M., Shi, S., \& Myers, S. R. (2019). A method for genome-wide genealogy estimation for thousands of samples. Nature Genetics, 51(9), 1321-1329. https://doi.org/10.1038/s41588-692019-0484-x

Takian, A., Rashidian, A., \& Doshmangir, L. (2015). The experience of purchaser-provider split in the implementation of family physician and rural health insurance in Iran: an institutional approach. HealthPolicyand Planning, 30, 1-11. https://doi.org/10.1093/heapol/czu135

Veneziano, L., \& Hooper, J. (1997). A method for quantifying content validity of health-related questionnaires. American Journal of Health Behavior, 21(1), 67-70.

Watkins, M. W. (2018). Exploratory factor analysis: A guide to be stpractice. Journal of Black Psychology, 44(3), $219-246$. https://doi.org/10.1177/0095798418771807

Yildirım, A. (2014). Nursing in the light of Health System and management principles. Ankara: Target Publishing. (Original work published in Turkish)

Yildırım, A. (2018). The importance of nurses ' participation in health policies and the factors affecting them. Visa E Journal of Nursing, 9(34), 1-7. (Original work published in Turkish)

Zon, R. T., Frame J. N., Neuss M. N., Page, R. D., Wollins, S. D., \& Stranne, S. (2016). American Society of Clinical Oncology policy statement on clinical pathways in oncology. Journal of Oncology Practice, 12(3), 261-265.

\section{TÜRKÇE GENİŞ ÖZET}

Bu çalışma, hemşireler için bir Politik Duyarllık Ölçeği geliştirmek ve geçerliliğini ve güvenirliğini ortaya koymak amacıyla gerçekleştirilmiştir. Metodolojik tasarımda hazırlanmıştır. Araştırmanın verileri Haziran 2017 ile Ocak 2018 arasında toplanmıştır. Araştırmaya katılan hemşire sayısı 300'dür. Ölçek maddeleri oluşturulurken öncelikli olarak bir madde havuzu hazırlanmıştır. Oluşturulan madde havuzunda toplam madde sayıs 86 'dır. Uzman görüşleri sonrasında madde havuzu 55 maddeden oluşmaktadır. Ölçek puanlaması 5'li Likert tipindedir. Ölçek puanlaması " 1 = hiç katılmıyorum, $2=$ çok az kattlıyorum, 3 = katılıyorum, 4 = oldukça katıliyorum, 5 = tamamen katılıyorum" arasındadır. Veriler SPSS 21 ve AMOS 22 programlarında değerlendirilmiştir. Verilerin analizinde "Yüzey ve Kapsam Geçerliliği, Açıklayıcı Faktör Analizi, Doğrulayıcı Faktör Analizi, Madde analizi, Cronbach Alpha, Spearman-Brown ve Guttman analizi ve Test-Tekrar Test Analizi Pearson Korelasyon Analizi” yöntemlerinden yararlanılmıştır. İlgili verilere normallik testi uygulanmış Skewness ve Kurtosis değerlerinin uygun değer aralığında olduğu görülmüsstür.

Hemşirelerin sosyo-demografik özellikleri incelendiğinde; \%69'u kadın, \%72.3'ü bekar, \%49'u lisans derecesine sahiptir; \%85.3'ü hafta sonları çalıștı̆ı, \%68.7'si özel hastanelerde çalıştı̆ı, \%42'si yoğun 
bakımda görev aldığı ve \% 86.3'ü mesleki derneklere üye olmadığ1 belirlenmiştir. Yaş ortalamas1 24.91 \pm 5.167 , aylık ortalama gelir (TL) $2098.36 \pm 662.200$ TL, ortalama çalş̧1lan y1l sayıs1 $4.4 \pm 4.004$, aynı kurumda çalışılan ortalama yıl sayısı $2.81 \pm 2.436$ ve haftalık ortalama çalışma süresi $47.04 \pm 6.554$ idi. Yüzey ve kapsam geçerliliği sağlanan taslak ölçekte faktör analizine başlamadan önce, örneklemin faktör analizi için uygunluğunu belirlemek için "Kaiser-Meyer-Olkin (KMO) ve Barlett Sphericity" testleri yapilmıştır. Taslak ölçeğin KMO değeri 0.874 'dür. Faktör yükü 0.40 'ın üzerinde olan maddelerin boyutlandırılmasında özdeğer katsayısı dikkate alınmaktadır. Özdeğer katsayısı birden yüksek dört sınır noktası bulunmuştur. Taslak ölçeğin faktör yükleri faktör 1 için 0.911 ila 0.958 arasindadır; faktör 2 için 0.562 ila 0.953 , faktör 3 için 0.926 ila 0.963 ve faktör 4 için 0.928 ila 0.950 arasındadır.

Taslak ölçeğin açılanan toplam varyansı \%91.92 olarak belirlenmiştir. İlk faktör için açıklanan varyans oran $\%$ 35.92'dir; ikinci faktör için\% 23.36; üçüncü faktör\% 19.67 ve dördüncü faktör için\% 12.97 'dir. Faktör rotasyonu için varimax rotasyon yöntemi kullanılmıştır. Faktör rotasyonu ölçeğin 1. alt boyutunun 17 maddeden $(3,4,5,8,10,13,14,16,17,19,21,27,28,31,38,39$ ve 43), 2. alt boyut 12 maddeden $(1,11,12,15,18,30,33,34,35,37,40$ ve 46), 3. alt boyutunun 9 maddeden $(9,22,23,24,25$, 47) oluşmaktadır. , 49, 50 ve 51) ve 4. alt boyutu 6 maddeden (45, 48, 52, 53, 54 ve 55) oluşmaktadır. Bir değişkenin faktör grubuna dahil edilmesi için, faktör yükünün en az 0.40 olmalıdır. Açıklayıcı faktör analizi sonrasında 11 maddenin faktör yük değerleri 0.40 ’n altında kaldığ için taslak ölçekten elenmiştir. 44 maddelik taslak ölçeğin dört boyut altında toplandığı belirlenmiştir. Boyutlara verilen isimler, maddelerin içeriği dikkate alınarak yapılmışır. 1. boyutta, bilgiyi ölçen ifadeler olması nedeniyle "bilgi" olarak isimlendirilirken; 2. boyutta, "biliş̧" olarak değerlendirilen genel bilgi düzeyine ilişkin ifadeler; 3. boyutta, politikaya katılımı ölçen ifadeler olması nedeniyle "katılım" olarak isimlendirilmiş ve 4. boyutta, politika ya olan ilgi düzeyini ölçmektedir.

Açımlayıcı faktör analizinde ortaya konan dört faktörlü yapının yapı geçerlilik testinin ikinci adımı Doğrulayıc1 Faktör Analizi gerçekleştirilmiştir. Her bir endeks için Reas et al. (2018) tarafından önerilen kabul edilebilir kesme değerleri dikkate alınmıştır. CFA analizi: " $\chi 2 / \mathrm{df}=1.92$, RMSEA $=0.06$, RMR $=$ 0.08 , IFI $=0.92$, CFI $=0.92$, GFI $=0.90$ ve AGFI $=0.87$ " idi. Ölçeğin güvenirlik analizi; madde analizi, Cronbach Alpha, Spearman-Brown, Guttman iç tutarlılık katsayıları ve test-tekrar test korelasyonları kullanılarak yapılmış ve uygun değer aralığında olduğu belirlenmiştir. Politik Duyarllılk Ölçeği'nin güvenilirlik çalsşması için 44 maddenin madde toplam puan korelasyonları incelenirken, bu maddelerin korelasyon katsayıları $\mathrm{r}=0.505$ ile 0.963 arasında değişmektedir $(\mathrm{p}<0.001)$. Politik Duyarllık Ölçeği'nin iç tutarllık katsayıları Cronbach Alpha için 0.958, Spearman-Brown için 0.894 ve Guttman için 0.865 olarak bulunmuştur. ölçeğin alt boyutları ile ilgili madde analizi ve iç tutarlılık katsayıları $(\mathrm{p}<0.01)$. Ölçek uyumlu test-tekrar test güvenilirliği elde edilmiştir $(\mathrm{p}<0.001)$. Sonuç olarak, dört alt boyut ve 44 maddeden oluşan nihai ölçekte, madde $3,4,5,8,10,13,14,16,17,19,21,27,28,31,38,39$ ve 43 bilgi düzeyi; madde 1, 11, $12,15,18,30,33,34,35,37,40$ ve 46 biliş seviyesi; $9,22,23,24,25,47,49,50$ ve 51 . maddeler katılımı ve $45,48,52,53,54$ ve 55 . maddeler ise ilgi düzeyini ölçmektedir.

Ölçek ifadelerinin puanlanmasında olumsuz madde bulunmamaktadır. 44 maddeden alınabilecek minumum puan 44 maksimum puan 220'dir. Alınan puanlar yükseldikçe katılımcıların politik duyarlılık düzeyleri de yükselmektedir. Alt bileşenlerde puan aralığı; bilginin alt boyutu için 17-85, bilişin alt boyutu için 12-60, katıllımın alt boyutu için 9-45 ve ilgi alt boyutu için 6-30'dur. Puanlar arttıkça bilgi, biliş, kattlım ve politikaya ilgi artmaktadır. Politik Duyarlılık Ölçeği istatistiksel olarak geçerli ve güvenilir bir araçtır. 